\title{
GAMBARAN PENGETAHUAN DOKTER GIGI TENTANG REKAM MEDIK GIGI
}

\author{
(THE KNOWLEDGE OF DENTISTRY ABOUT THE MEDICAL RECORD OF DENTAL \\ NATIONAL STANDARDS)
}

\author{
Murniwati $^{1}$, Rizanda Machmud ${ }^{2}$, Suci Rahmasari $^{3}$
}

\begin{abstract}
Abstrak
Dental record yang digunakan harus sesuai dengan Standar Nasional Rekam Medik Kedokteran Gigi yaitu harus memuat data identitas pasien, keadaan umum pasien, odontogram, data perawatan kedokteran gigi serta nama dan tanda tangan dokter gigi dan yang lebih penting dental record harus diisi secara lengkap. Penelitian ini bertujuan untuk mengetahui pengetahuan dokter gigi terhadap kelengkapan rekam medik gigi yang sesuai standar nasional. Desain penelitian ini adalah Deskriptif. Populasi adalah semua dokter gigi yang bekerja di Puskesmas dan Rumah Sakit Kota Padang. Teknik pengambilan sampel yang digunakan adalah Total Sampling dan pengumpulan data dilakukan melalui kuisioner dan observasi terhadap rekam medik gigi. Hasil penelitian menunjukkan bahwa tingkat pengetahuan dokter gigi mengenai pentingnya rekam medik gigi yang sesuai standar nasional masih kurang. Pengetahuan mengenai aspek medikolegal merupakan pokok bahasan yang tingkat pengetahuannya sangat rendah yaitu hanya mencapai 4,2\%. Kurangnya pengetahuan dokter gigi mengenai Rekam Medik Gigi yang sesuia standar nasinal disebabkan kurangnya sosialisasi dan belum digunakannya rekam medic gigi yang sesuai standar nasional. Perlu adanya sosialisasi dan kebijakan yang mengatur penggunaan rekam medic gigi yang sesuai standar nasional
\end{abstract}

Kata kunci : Dental record, odontogram, medikolegal, rekam medik

\begin{abstract}
Dental records must comply with National Standard of Dentistry, Medical Record must contain data that identity of the patient, patient's general condition, odontogram, dental care data and the name and signature of the dentist and dental records are more important filled completely. This study aim to know the knowledge of all dentists in Padang to dentall record. The design of this study is Descriptive. The populations in this study were all dentists who working in health centers and hospitals of Padang. The sampling technique is Total Sampling and data collection through questionnaires and observation of dental records. The results showed that the rate of the level of knowledge about the importance of dentall record low according to national standards where knowledge about medikolegal aspects is the subject to a level of knowledge is low, reaching only $4.2 \%$. Knowledge of dentists about the medical records dental national standards is low because of the lock of socialization and conducted a related-party factor. It could be need to socialization and provide the policy of dental record based on national standard for all dentists.
\end{abstract}

Key words : Dental Record, odontogram, medicolegal, medical records

\footnotetext{
${ }^{1}$ Staf Fakultas Kedokteran Gigi Universitas Andalas

${ }^{2}$ Staf Fakultas Kedokteran Universitas Andalas

${ }^{3}$ Mahasiswa Fakultas Kedokteran Gigi Universitas Andalas
} 


\section{PENDAHULUAN}

Dokter gigi selaku tenaga profesional bidang kesehatan diwajibkan membuat rekam medik dalam menjalankan praktek kedokteran giginya, dengan cara melengkapi rekam medik gigi setiap selesai memberikan pelayanan kesehatan pada pasiennya. Kelengkapan rekam medik gigi selain ditanda tangani oleh dokter gigi yang memberikan pelayanan atau tindakan, juga harus mengikuti cara penulisan (nomenklatur) yang berlaku secara internasional, sehingga rekam medik dapat bermanfaat, berkaitan dengan aspek hukum bagi masyarakat maupun sebagai sarana identifikasi dalam upaya pemeriksaan forensik. $^{1}$

Standar Nasional Rekam Medik Kedokteran Gigi menurut Undang-Undang No.29 tahun 2004 adalah berkas yang berisi catatan dan dokumen tentang identitas pasien, pemeriksaan, pengobatan, tindakan dan pelayanan yang telah diberikan kepada pasien. Berdasarkan Pedoman Standar Nasional Rekam Medik Kedokteran Gigi Tahun 2007 rekam medik gigi berisi : identitas pasien, keadaan umum pasien, odontogram, data perawatan kedokteran gigi, nama dokter gigi yang merawat. ${ }^{1}$
Hasil Diskusi Kongres Perhimpunan Perekam Medis dan Informasi Kesehatan Indonesia menyimpulkan bahwa kesulitan yang dialami oleh para petugas maupun pengelola unit Rekam Medis semakin berat dengan perilaku dokter dan dokter gigi yang kurang peduli terhadap pengisian rekam medis dan rekam medik gigi. Salah satu faktor yang mempengaruhi perilaku dokter gigi diantaranya adalah tingkat pengetahuan. Namun hal tersebut harus diteliti lebih lanjut apakah benar faktor "ketidaktahuan" dokter dan dokter gigi tentang pengisian rekam medik yang baik dan benar ataukan faktor-faktor lain yang menyebabkan kelengkapan data pada rekam medik (dental record). ${ }^{2}$

Kota Padang sebagai ibu kota Propinsi memiliki jenis sarana kesehatan yang cukup beragam. Di lingkungan Dinas Kesehatan Kota Padang terdapat sarana kesehatan diantaranya berupa Puskesmas dan Rumah Sakit. Dari laporan tahunan DKK Kota Padang terdapat 20 Puskesmas dan 26 Rumah Sakit yang masih beroperasi, terdapat 43 orang dokter gigi yang bertugas di Puskesmas dan beberapa dokter gigi yang bertugas di Rumah Sakit. ${ }^{3,4}$

Berdasarkan hasil uji coba kuisioner mengenai rekam medik gigi, didapat hasil 
masih banyak dokter gigi di Puskesmas dan Rumah Sakit yang kurang mengetahui mengenai pentingnya rekam medik gigi yang sesuai dengan standar nasional kedokteran gigi yang meliputi manfaat, syarat lengkap, aspek medikolegal dan item penting yaitu odontogram.

Peraturan Mentri Kesehatan Republik Indonesia Nomor 269/Menkes/Per/III/2008 menyatakan bahwa rekam medic adalah keterangan baik yang tertulis/terekam tentang identitas pasien, anamnesa, penentuan fisik, laboratorium, diagnosa segala pelayanan dan tindakan yang diberikan kepada pasien dan pengobatan baik di rawat jalan, rawat inap, dan gawat darurat. Departemen Kesehatan Republik Indonesia dalam Undang-Undang No.29 Tahun 2004 rekam medic adalah berkas yang berisikan catatan dan dokumen tentang identitas pasien, pemeriksaan, pengobatan, tindakan dan pelayanan lain kepada pasien. Menurut Departemen Kesehatan RI (1997) Falsafah rekam medis mencantumkan nilai-nilai aspek yang dikenal sebagai sebutan ALFREDS (Adsminitrative, Legal, Financial, Research, Education, Documentation and Service) yaitu sebagai berikut: ${ }^{5}$

\section{Administrative}

(Aspek

Adsministrasi)
Berkas rekam medis dikatakan mempunyai aspek adsministrasi, karena isinya menyangkut tindakan berdasarkan wewenang dan tanggung jawab sebagai tenaga medis dan paramedis dalam mencapai tujuan pelayanan kesehatan.

2. Legal (Aspek Hukum)

Berkas rekam medis mempunyai nilai hukum, karena isinya menyangkut masalah adanya jaminan kepastian hukum atas dasar keadilan, dalam rangka usaha menegakkan hukum serta penyedian bahan tanda bukti untuk menegakkan keadilan.

\section{Financial (Aspek Keuangan)}

Berkas rekam medis mempunyai nilai uang, karena isinya mengandung data atau informasi yang dapat dipergunakan sebagai aspek keuangan.

4. Research (Aspek Penelitian)

Berkas rekam medis mempunyai nilai penelitian, karena isinya menyangkut data atau informasi yang dapat digunakan sebagai pengembangan ilmu pengetahuan dan penelitian di bidang kesehatan.

5. Education (Aspek Pendidikan) 
Berkas rekan medis mempunyai nilai pendidikan, karena isinya menyangkut data atau informasi tentang perkembangan kronologis (terurut) dan kegiatan pelayan medik yang diberikan kepada pasien, informasi tersebut dipergunakan sebagai bahan referensi pengajaran bidang profesi pemakai.

\section{Documentation}

(Aspek

Dokumentasi)

Berkas rekam medis mempunyai nilai dokumentasi, karena isinya menyangkut sumber ingatan yang harus didokumentasikan dan dipakai sebagai bahan pertanggung jawaban dan laporan rumah sakit.

7. Service (Aspek Medis)

Aspek Medikolegal Rekam Medis menurut UU RI No 29 tahun 2004 tentang

Praktek

Kedokteran/Kedokteran gigi Pasal 46 adalah :6

1) Setiap dokter atau dokter gigi dalam menjalankan praktek kedokteran wajib membuat rekam medis.

2) Rekam medis sebagaimana yang dimaksud di atas harus dibuat segera dan dilengkapi setelah pasien menerima pelayanan.

3) Pembuatan rekam medis dilakukan melalui pencatatan dan dokumentasi hasil pemeriksaan, pengobatan, tindakan dan pelayanan lain yang telah diberikan kepada pasien.

4) Setiap pencatatan ke dalam rekam medis harus dibubuhi nama, waktu dan tanda tangan dokter, dokter gigi atau tenaga kesehatan tertentu yang memberikan pelayanan langsung.

5) Dalam hal terjadinya kesalahan dalam melakukan pencatatan pada rekam medik dapat dilakukan pembetulan.

6) Pembetulan sebagaimana yang disebutkan di atas hanya dapat dilakukan dengan pencoretan tanpa menghilangkan catatan yang dibetulkan dan dibubuhi paraf dokter, dokter gigi dan tenaga kesehatan yang bersangkutan.

Hal ini dipertegas dengan Peraturan Mentri

Kesehatan

RI 
No1419/MENKES/Per/X/2005 Pasal 16 tentang aspek medikolegal rekam medis $:^{6}$

1) Dokter dan Dokter Gigi dalam pelaksanaan praktek kedokteran wajib membuat rekam medis.

2) Rekam medis sebagaimana dimaksud pada ayat (1) dilaksanakan sesuai ketentuan perundang-undangan.

Dalam Surat Keputusan Menteri Kesehatan No. 749a/Menkes/Per/XII/1989 dinyatakan bahwa setiap sarana pelayanan kesehatan wajib membuat rekam medis, dan dilakukan oleh dokter, dokter gigi dan tenaga kesehatan lainnya yang memberikan pelayanan kepada pasien. ${ }^{7}$

Berdasarkan standar nasional rekam medik kedokteran gigi, tujuan pembuatan rekam medik gigi diantaranya :

1. Sebagai catatan mengenai keadaan gigi dan keluhan pasien saat datang, diagnosa dan perawatan yang dilakukan pada setiap kunjungan.

2. Sebagai dasar untuk menentukan tindakan yang akan dilakukan pada kunjungan berikutnya.

3. Catatan sebagai sejarah penyakit, perawatan sebuah gigi, tindakan yang telah atau pernah dilakukan pada sebuah gigi, sehingga dapat membantu diagnosa dan rencana perawatan selanjutnya.

4. Catatan mengenai keadaan umum pasien yang perlu diperhatikan, yang perlu dipertimbangkan dalam keputusan perawatan/pengobatan.

5. Sebagai data resmi/legal untuk pertanggung jawaban dokter gigi atas segala tindakan perawatan dan pengobatan yang telah dilakukan.

6. Gambaran mengenai kondisi kesehatan gigi pasien secara keseluruhan.

7. Sebagai sumber data untuk keperluan identifikasi jika diperlukan.

Kelengkapan isi Rekam Medik Kedokteran Gigi menurut pedoman Standar Nasional Rekam Medik Kedokteran Gigi adalah: ${ }^{1}$

1. Identitas pasien

Data identitas pasien yang berisi: nomor file, tanggal pembukaan status, nama, jenis kelamin, tempat dan tanggal lahir/umur, alamat rumah, nomor telepon rumah dan handphone, pekerjaan, alamat kantor, nomor telepon kantor dan faximile. Identitas ini diisi saat pertama kali pasien datang 
2. Keadaan umum pasien

Data keadaan umum pasien dalam rekam data gigi minimal berisi :Golongan darah., Tekanan darah normal (adakah kelainan tekanan darah) dan penyakit sistemik.

3. Odontogram

Odontogram berisi data tanggal pemeriksaan untuk odontogram, gambar denah gigi (odontogram), hubungan oklusi, torus palatinus, torus mandibularis., tipe langitlangit mulut (palatum), ada atau tidaknya gigi berlebih (supernumery), ada atau tidaknya diastema sentral., adakah anomaly atau ciri-ciri lainnya. Pembuatan odontogram diulangi atau dilengkapi pada setiap kunjungan selanjutnya..

4. Data perawatan kedokteran gigi

Data perawatan kedokteran gigi berisi: tanggal kunjungan, gigi yang dirawat, keluhan dan diagnose, tindakan yang dilakukan, paraf dokter gigi, Rontgen foto, intra oral digital foto jika ada.

5. Nama dokter gigi yang merawat.

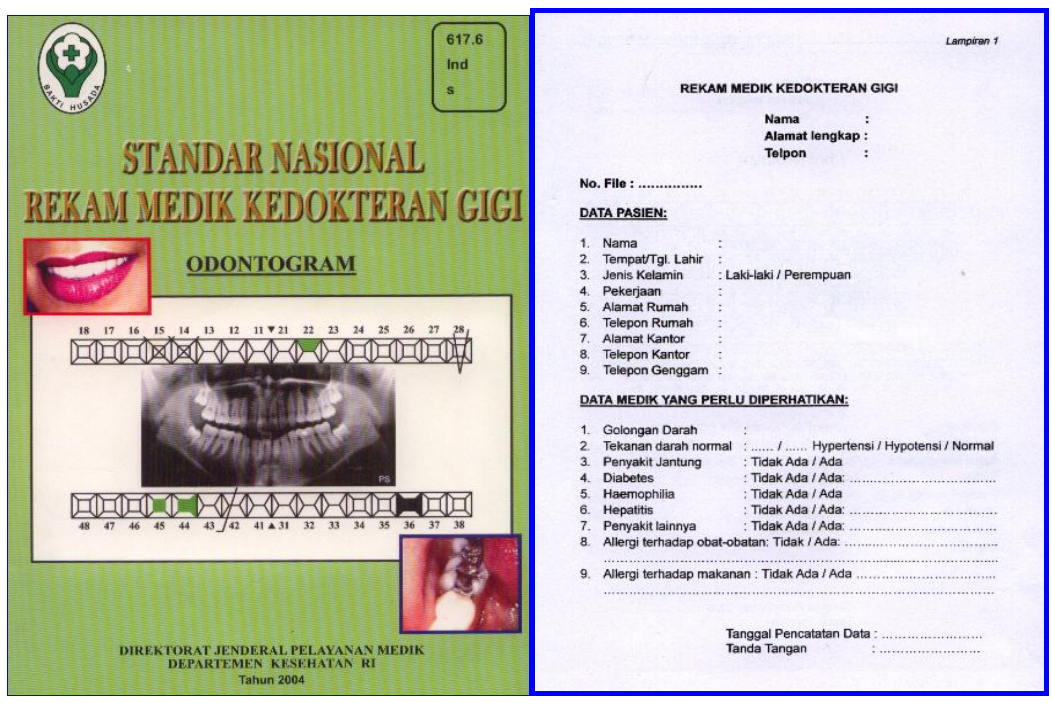




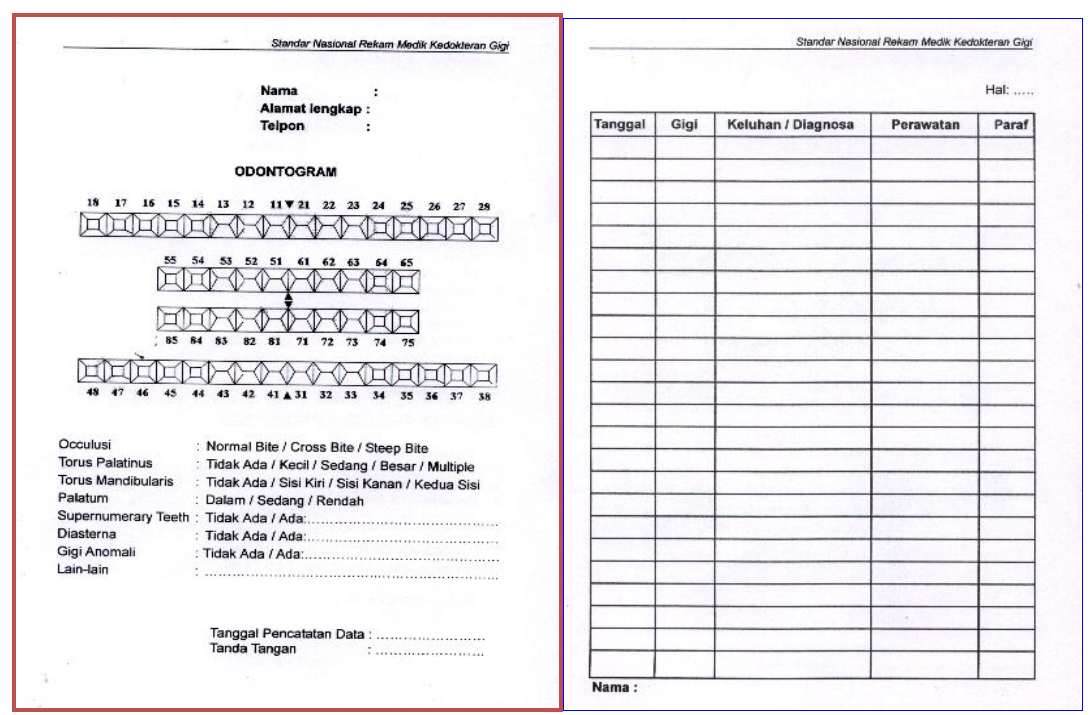

Gambar .1 Contoh Rekam Medik Gigi yang sesuai dengan Standar Nasional

Rekam Medik Kedokteran gigi (Standar Nasional Rekam Medik Kedokteran Gigi, 2007).

Penulisan nomenklatur gigi dan odontogram rekam medic kedokteran gigi disarankan menggunakan 2 digit dari FDI (Federation Dentaire Internationale) / Interpol (International Police) dan Universal Sistem. ${ }^{8}$

1. Sistem FDI ( Sistem 2 digit )

Gigi permanen,rahang dibagi menjadi 4 kuadran dan tiap kuadran gigi diberi angka 1 sampai 8 :

1) Angka 1, untuk rahang atas kanan.

2) Angka 2, untuk rahang atas kiri

3) Angka 3, untuk rahang bawah kiri.
4) Angka 4, untuk rahang bawah kanan.

Gigi sulung, rahang dibagi menjadi 4 kuadran dan diberi angka 1 sampai 5

1) Angka 5, untuk rahang atas kanan.

2) Angka 6, untuk rahang atas kiri.

3) Angka 7, untuk rahang bawah kiri.

4) Angka 8, untuk rahang bawah kanan.

Pengetahuan merupakan hasil dari tahu dan terjadi setelah orang melakukan pengindraan terhadap suatu objek tertentu. Pengindraan terjadi melalui panca indra 
manusia, yakni : indra penglihatan, pendengaran, penciuman, rasa, dan raba. Sebagian besar pengetahuan manusia diperoleh dari mata dan telinga. Melalui membaca dan mendengar berita. Maka, pengetahuan merupakan dominan yang sangat penting untuk terbentuknya tindakan seseorang. ${ }^{9}$

Pengetahuan seseorang dipengaruhi oleh beberapa faktor yaitu :

1. Faktor internal : faktor dari dalam diri sendiri, misalnya intelegensia, minat, kondisi fisik.

2. Faktor eksternal : faktor dari luar diri, misalnya keluarga, masyarakat, sarana.

3. Faktor pendekatan belajar : faktor upaya belajar, misalnya strategi dan metode dalam pembelajaran.

Penelitian Rogers menyatakan bahwa sebelum orang mengadopsi perilaku baru (berperilaku baru), maka di dalam diri orang tersebut terjadi proses yang berurutan yaitu :

1. Awareness (kesadaran), dimana orang tersebut menyadari dalam arti mengetahui terlebih dahulu terhadap stimulus (objek).
2. Interest (merasa tertarik) terhadap stimulus atau objek tersebut. Di sini sikap subjek sudah mulai timbul.

3. Evaluation (menimbang-nimbang) terhadap baik dan tidaknya stimulus tersebut bagi dirinya. Hal ini berarti sikap responden sudah lebih baik lagi.

4. Trial, di mana subjek mulai mencoba melakukan sesuatu sesuai dengan apa yang dikehendaki oleh stimulus.

5. Adoption, di mana subjek telah berperilaku baru sesuai dengan pengetahuan, kesadaran, dan sikapnya terhadap stimulus.

Apabila perilaku baru didapat melalui proses yang didasarkan oleh pengetahuan, kesadaran dan sikap yang positif maka perilaku tersebut akan bersifat langgeng (long lasting). Sebaliknya apabila perilaku itu tidak didasarkan oleh pengetahuan dan kesadaran akan tidak berlangsung lama.

Pengukuran pengetahuan dapat dilakukan dengan wawancara atau kuisioner yang menanyakan tentang isi materi yang ingin diukur dari subjek penelitian atau responden. Kedalaman pengetahuan yang ingin kita ketahui atau 
kita ukur dapat kita sesuaikan dengan tingkat-tingkat tersebut di atas. ${ }^{9}$.

Pengetahuan dibagi 3 kategori yaitu $:^{10}$

1. Baik : $76 \%-100 \%$,

2. Cukup : $60 \%-75 \%$

3. Kurang : $<55 \%$

Pengetahuan dalam penelitian ini adalah untuk menilai segala sesuatu yang diketahui informan (dokter gigi) mengenai dental record yang sesuai dengan standar nasional kedokteran gigi.

\section{MATERI DAN METODE}

Desain penelitian yang digunakan adalah Deskriptif. Penelitian ini bertujuan untuk melihat bagaimana gambaran atau deskripsi tentang suatu keadaan yang objektif. Penelitian ini dilakukan kepada dokter gigi yang bertugas di Puskesmas dan Rumah Sakit Kota Padang. Penelitian dilakukan pada bulan Januari 2012.

\section{Data Primer}

Data primer adalah data yang diperoleh dari hasil kuisioner yang ditanyakan kepada dokter gigi dengan pertanyaan yang berhubungan dengan dental record untuk mendapatkan gambaran pengetahuan dokter gigi terhadap rekam medik gigi yang sesuai Standar Nasional Rekam Medik Kedokteran Gigi.

\section{Data sekunder}

Data sekunder adalah data jumlah dokter gigi yang bertugas di Puskesmas dan Rumah Sakit Kota Padang. Data alamat Puskesmas dan Rumah Sakit Kota Padang.

Analisa Data Analisa variable dilakukan untuk melihat distribusi frekuensi dari pengetahuan doketr gigi mengenai rekam medic gigi sesuai standar nasinal kedokteran gigi

\section{HASIL PENELITIAN DAN PEMBAHASAN}

Pada penelitian ini, dokter gigi yang menjadi sampel adalah dokter gigi yang bertugas di Puskesmas, Rumah Sakit Umum Pemerintah dan Rumah Sakit Umum Swasta di Kota Padang. Karakteristik responden dapat dilihat pada tabel di bawah ini. 
Tabel 1 Distribusi Frekuensi Karakteristik Dokter Gigi di Puskesmas dan Rumah Sakit Kota Padang Tahun 2012

\begin{tabular}{lcc}
\hline \multicolumn{1}{c}{ Karakteristik } & F & \% \\
\hline Jenis Kelamin & 5 & 10,4 \\
\hline Perempuan & 43 & 89,6 \\
\hline Jumlah & $\mathbf{4 8}$ & $\mathbf{1 0 0}$ \\
\hline \multicolumn{1}{c}{ Umur } & 7 & 14,6 \\
\hline Dewasa awal & 21 & 43,8 \\
\hline Dewasa muda & 17 & 35,4 \\
\hline Dewasa madya & 3 & 6,3 \\
\hline Dewasa lanjut & $\mathbf{4 8}$ & $\mathbf{1 0 0}$ \\
\hline Jumlah & & 52,1 \\
\hline \multicolumn{1}{c}{ Lama kerja } & 25 & 47,9 \\
\hline Baru & 23 & $\mathbf{1 0 0}$ \\
\hline Lama & $\mathbf{4 8}$ & \\
\hline Jumlah & & \\
\hline
\end{tabular}

Distribusi frekuensi karakteristik dokter gigi di Puskesmas dan Rumah Sakit Kota Padang menunjukkan bahwa sebagian besar dokter gigi berjenis kelamin perempuan yaitu sebanyak 43 dokter gigi ( 89,6\% ) dan 21 dokter gigi ( $43 \%$ ) tergolong kedalam kelompok umur dewasa muda (30-40 tahun) sedangkan lama kerja masing-masing dokter gigi hampir sama. Lebih dari separuh dokter gigi yang telah bekerja di Puskesmas dan Rumah Sakit selama kurang dari 10 tahun yaitu sebanyak 25 dokter gigi ( $52,1 \%$ )

Pengetahuan dokter gigi mengenai pentingnya dental record yang terdiri dari syarat lengkap, manfaat, aspek medikolegal dan item penting dental record dapat dilihat pada tabel dibawah ini: 


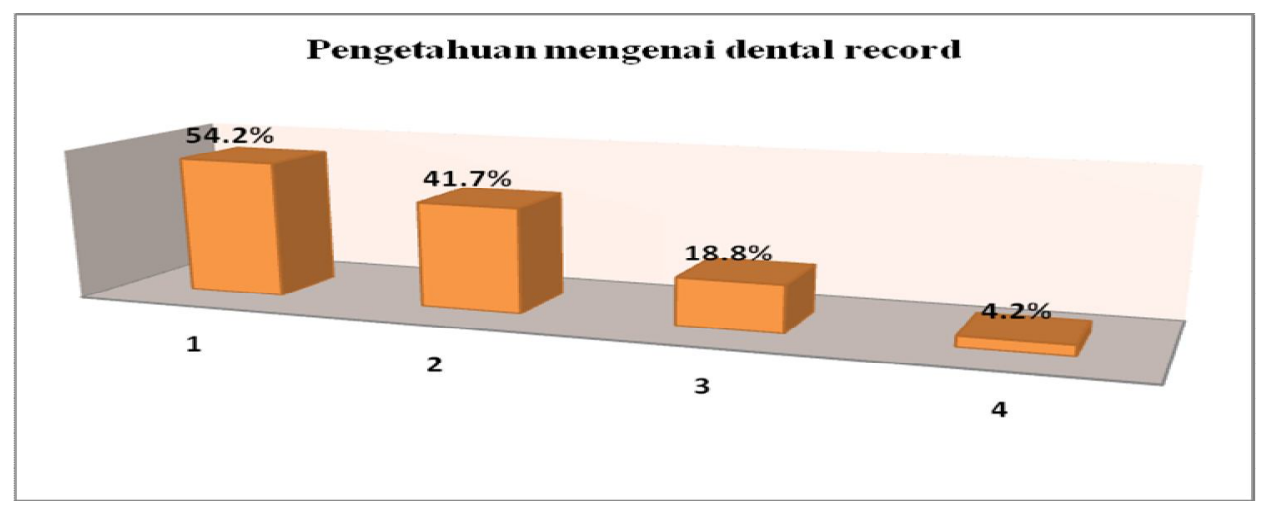

Grafik 1. Distribusi Frekuensi Pengetahuan Dokter Gigi Mengenai Dental

Record di Puskesmas dan Rumah Sakit Kota Padang Tahun 2012

Keterangan: 1 = Pengetahuan mengenai syarat lengkap dental record.

$2=$ Pengetahuan mengenai item penting dental record .

3 = Pengetahuan mengenai manfaat dental record.

4 = Pengetahuan mengenai aspek medikolegal dental record.

Dari grafik di atas tingkat pengetahuan dokter gigi di Puskesmas dan Rumah Sakit Kota Padang secara keselurahan masih kurang. Dari keempat pokok bahasan yang diujikan pengetahuan dokter gigi terendah terdapat pada pokok bahasan mengenai aspek medikolegal yaitu hanya sebesar 4,2\%. Pengetahuan dokter gigi mengenai syarat dental record masih rendah karena pengetahuan dikatakan cukup apabila mempunyai nilai $60-75 \%$.

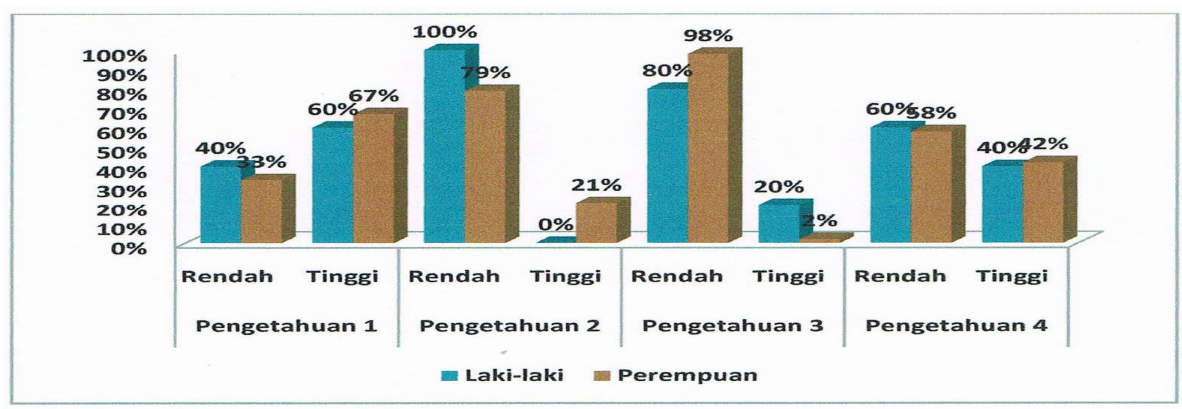

Grafik 2. Distribusi Pengetahuan Dokter Gigi Mengenai Dental Record di Puskesmas dan Rumah Sakit Kota Padang Tahun 2012 Berdasarkan Jenis Kelamin 
Dari grafik di atas tingkat pengetahuan dokter gigi di Puskesmas dan Rumah Sakit Kota Padang berdasarkan jenis kelamin di atas dapat dilihat bahwa untuk pengetahuan tentang mamfaat Dental Record ( pengetahuan 2) semua dokter gigi laki-laki (100\%) mempunyai pengetahuan rendah. Untuk pengetahuan syarat lengkap Dental Record (pengetahuan 1) dan item penting Dental Record (pengetahuan 4) baik dokter gigi laki-laki maupun perempuan mempunyai tingkat pengetahuan hampir sama. Sedangkan pengetahuan tentang mamfaat Dental Record (pengetahuan 2) dan aspek medicolegal (pengetahuan 3) dokter gigi laki-laki dan perempuan mempunyai tingkat pengetahuan rendah.

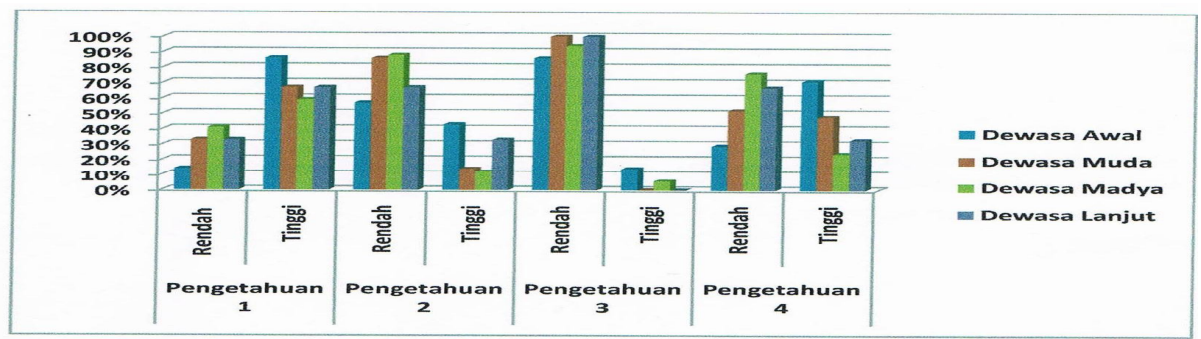

Grafik 3. Distribusi Pengetahuan Dokter Gigi Mengenai Dental Record di Puskesmas dan Rumah Sakit Kota Padang Tahun 2012 Berdasarkan Usia

Dari grafik di atas tingkat pengetahuan dokter gigi di Puskesmas dan Rumah Sakit Kota Padang berdasarkan usia, dokter gigi dewasa awal mempunyai tingkat pengetahuan paling tinggi untuk syarat lengkap Dental Record (pengetahuan 1). Dokter gigi dewasa muda dan dewasa lanjut mempunyai tingkat pengetahuan paling rendah untuk aspek medicolegal (pengetahuan 3).

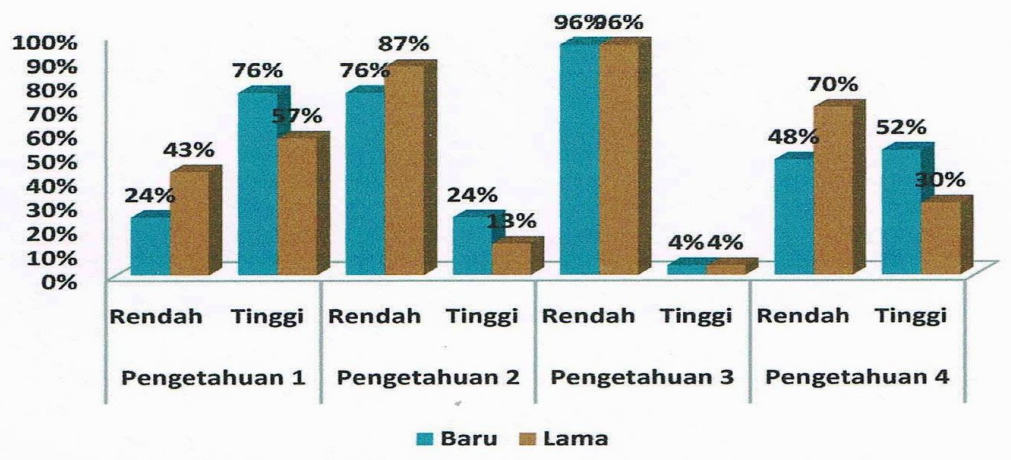

Grafik 4. Distribusi Pengetahuan Dokter Gigi Mengenai Dental Record di Puskesmas dan Rumah Sakit Kota Padang Tahun 2012 Berdasarkan Lama Kerja 
Dari grafik di atas tingkat pengetahuan dokter gigi di Puskesmas dan Rumah Sakit Kota Padang berdasarkan lama kerja didapat baik masa kerja baru maupun lama hanya $4 \%$ dokter gigi masa kerja lama dan baru yang mempunyai pengetahuan yang tinggi terhadap aspek medikolegal dental record (pengetahuan 3). Untuk pengetahuan tentang syarat lengkap dental record (pengetahuan 1) dokter gigi masa kerja baru mempunyai tingkat pengetahuan lebih tinggi dibandingkan dokter gigi masa kerja lama.

\section{KESIMPULAN DAN SARAN}

Hasil penelitian ini memperlihatkan bahwa tingkat pengetahuan dokter gigi di Puskesmas dan Rumah Sakit Kota Padang terhadap syarat lengkap, item penting, manfaat dan aspek medikolegal rekam medic gigi masih rendah yaitu kurang dari $55 \%$. Hal ini kemungkinan disebabkan oleh tidak tersedianya sarana rekam medik gigi yang sesuai standar nasional. Perlu adanya kebijakan dari institusi yang berwenang untuk membuat dan mensosialisasikan rekam medik gigi sesuai standar nasional.

\section{KEPUSTAKAAN}

1. Direktorat Jendral Bina Pelayanan Medik Departemen Kesehatan RI. 2007. Standar Nasional Rekam Medik Kedokteran Gigi. Departemen Kesehatan RI Cetakan II.Jakata.

2. Salami. 2008. Hubungan Pengetahuan dan Motivasi Dengan Perilaku Dokter Gigi Spesialis Dalam Pengisian Rekam Medis Di Badan Pelayanan Kesehatan Rumah Sakit Umum Sigli. Sekolah Pascasarjana Universita Sumatra Utara. Medan.

3. Dinas Kesehatan Kota.2011. Laporan Tahunan tahun 2010 Edisi 2011. Dinas KesehatanKota Padang.

4. Dinas Kesehatan Kota. 2011. Profil Kesehatan Kota tahun 2010 Edisi 2011. Dinas Kesehatan Kota Padang.

5. Departemen Kesehatan RI. 2008. Peraturan Mentri Kesehatan RI No.269/Menkes/Per/III/2008 tentang Rekam Medis. Jakarta, Depkes RI.

6. Departemen Kesehatan RI. 2004. UndangUndang Republik Indonesia No. 29 Tahun 2004 tentang Praktek Kedokteran. Jakarta.

7. Departemen Kesehatan RI. 1989. Peraturan Menteri Kesehatan No.749a/Men.Kes/Per/XIII/1989 Tentang Rekam Medis/Medical Record. Jakarta.

8. Kepolisian Negara Republik Indonesia Markas Besar. 2011. Penyampaian Formulir Odontogram. Jakarta.

9. Konsil Kedokteran Indonesia. 2006. Manual Rekam Medis. Kodokteran Indonesia.

10. Arikunto, S. 2003. Manajemen Penelitian. Rineka Cipta. Jakarta.

11. Charangowda. 2010. Dental Recors : An Overview. Journal of Forensic Dental Sciences/January-June 2010/ Vol 2/ Issue 1 